\title{
Historical reconstruction of sturgeon (Acipenser spp.) spatiotemporal distribution and causes for their decline in North-Western Europe
}

\author{
Niels W. P. Brevé ${ }^{1,2,3}$ (D) . Leopold A. J. Nagelkerke ${ }^{1}$ (D) Anthonie D. Buijse ${ }^{1,4}$ (D) \\ Theodorus J. van Tuijn ${ }^{5}$ (D) AlberTinka J. Murk ${ }^{2}$ (D) - Hendrik V. Winter ${ }^{1,6}$ (D) \\ H. J. Rob Lenders ${ }^{5}$ (D)
}

Received: 22 July 2021 / Revised: 14 January 2022 / Accepted: 25 January 2022 /

Published online: 15 February 2022

(C) The Author(s) 2022

\begin{abstract}
This study aims to reconstruct the historical spatiotemporal distribution of the anadromous sturgeons, Acipenser sturio and A. oxyrinchus, in NW-Europe (especially in the Rhine, Meuse, Scheldt, and Ems rivers, and in the North Sea), in light of evaluating the possibilities for their reintroduction. It is based on fisheries data from the 14th-twentieth century, consisting of $>5000$ records of sturgeon landings and sales (c. 40,000 specimens) from the Netherlands, Belgium, Germany, Luxemburg, France and Switzerland. Most data originate from fisheries in the Rhine-Meuse delta (c. 28,000 specimens, 98\% of the Rhine catches). Further upstream, far fewer sturgeons (c. 600 specimens) were reported from the Rhine's mainstem and its principal tributaries, Mosel, Neckar and Main. Smaller tributaries and the Ems, Meuse, and Scheldt rivers seldom yielded sturgeons. This spatial pattern can be related to the species' preference for large-river habitat, combined with fisheries activities that were most intensive in the delta areas. Sturgeon catches began to dwindle in the late nineteenth century, at a time when river engineering first strongly affected the sturgeon's reproductive habitats in the Lower Rhine and delta areas. Also from then onwards, North Sea fishery pressure increased, as trawlers switched from sail to steam-powered propulsion. These sea fisheries harvested all age-classes of sturgeons year-round, including populations from other European rivers. The outcomes strongly suggest that NW-European sturgeon populations were initially impacted by intensive river fisheries, but especially by destruction of reproductive habitat, due to river regulation, and an intensified North Sea fishery, ultimately resulting in total population collapse.
\end{abstract}

Keywords European sturgeon (Acipenser sturio) - Atlantic sturgeon (Acipenser oxyrinchus $) \cdot$ Historical biogeography $\cdot$ Overfishing $\cdot$ River engineering $\cdot$ Steam trawl fishery

Communicated by Paul Humphries.

Niels W. P. Brevé

niels.breve@wur.nl

Extended author information available on the last page of the article 


\section{Introduction}

Sturgeons (order Acipenseriformes; sturgeons and paddlefish) only occur in the Northern Hemisphere (Billard and Lecointre 2000). Most sturgeons are long-lived, large-bodied, late-maturing fish that undertake long-distance anadromous migrations through marine, estuarine and riverine habitats (Bemis and Kynard 1997). Due to these life history characteristics and their anadromous nature, sturgeon populations are easily affected by (marine) overfishing and river engineering. This includes dredging, diking, canalisation, and barriers to upstream and downstream migration due to weirs, dams, sluices and hydropower plants, amongst others (Rochard et al. 1990; Birstein et al. 1997; Puijenbroek et al. 2019). According to the IUCN Red Data List, at present $85 \%$ of all Acipenseriformes are endangered, making it the most threatened order of vertebrates in the world. This conservation status is a wake-up call to restore their populations, migration routes, and core habitats in their natal rivers and estuaries (for spawning, nursery, and salt/freshwater acclimatisation).

This study aims to reconstruct the historical spatiotemporal distribution of sturgeons in the river Rhine and in the adjacent Ems, Meuse and Scheldt rivers (Fig. 1). Two sturgeon species from the north Atlantic Ocean, the now critically endangered European sturgeon (Acipenser sturio) (Gesner et al. 2010) and the near threatened Atlantic sturgeon (Acipenser oxyrinchus) used to display extensive homing behaviour to these rivers (Van Neer et al. 2012; Thieren et al. 2016). These sturgeon species, that represent a separate clade distinct from all other Acipenseriformes (Thieren et al. 2015), were strongly impacted during the nineteenth and twentieth centuries. While Atlantic sturgeon populations survived on the North American side of the Atlantic Ocean, this species became extinct in Europe (Williot et al. 2002; Gessner et al. 2006; Chassaing et al. 2016), but was recently reintroduced in the river Oder and the Baltic Sea (Gessner et al. 2010; Kolman et al. 2011). The European sturgeon, which only occurs on the European side of the Atlantic Ocean, was barely saved from global extinction during the 1990's, when 53 specimens were collected from a relict population in the Gironde basin in France (Williot and Castelnaud 2011). These specimens were raised to build an ex situ brood stock in Bordeaux and another one in Berlin, for restocking fry and fingerlings in the Gironde and Elbe river basins (Williot and Kirschbaum 2011).

As a result of the restocking efforts, in recent years hundreds of European sturgeon juveniles and adolescents have been observed in neritic zones of the northeast Atlantic Ocean (Council of Europe 2018; OSPAR Commission 2021). Although the species' status is still critical, as no natural reproduction is yet observed, this gives rise to consideration of the expansion of restoration efforts. The species' core habitat in the Mediterranean (Chassaing et al. 2016) is almost completely lost due to substantial anthropogenic impacts, like dams and human-induced climate change (droughts, increased temperatures) (Williot et al. 2002; Lassalle et al. 2010), making recovery virtually impossible. In contrast, the river Rhine (from now on: Rhine) has an intact longitudinal connectivity between the North Sea, the Port of Rotterdam, and the upper reaches, over 850 river kilometres upstream (ICPR 2018). In addition, remediation of 18th-twentieth century industrial pollution (VillamayorTomas et al. 2014) has further improved the Rhine's carrying capacity for diadromous fishes (Borcherding et al. 2010; Hundt et al. 2015). To strengthen the conservation status in the species' northern range, the possibility of re-introducing the European sturgeon in the Rhine is currently under assessment, which includes experimental releases of tagged individuals (Brevé et al. 2014, 2019). However, before actual restocking of this river can be implemented, a thorough habitat feasibility and risk assessment is paramount to reduce 


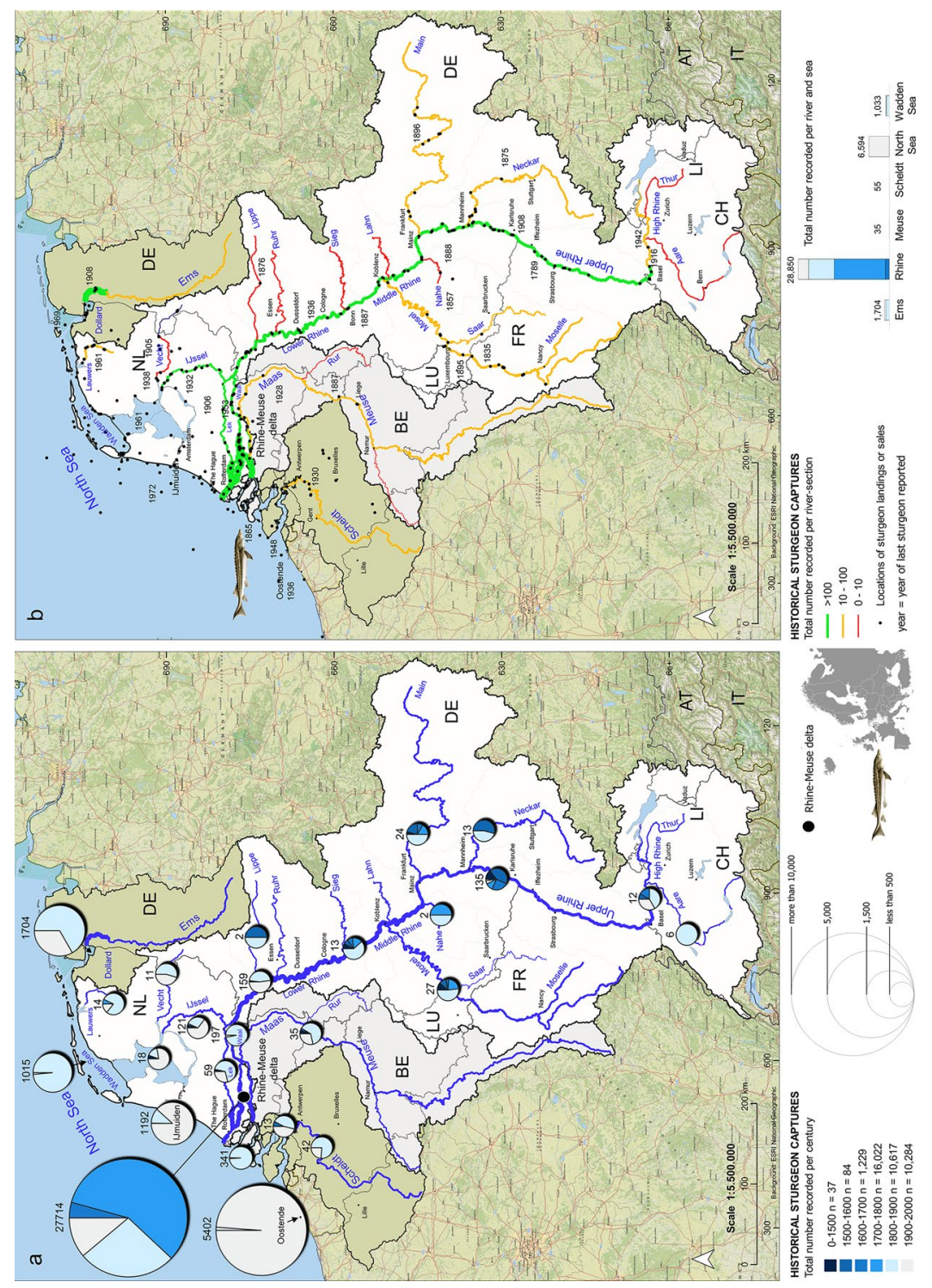

क को

边 0

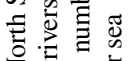

之元

Ð 형 흐

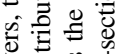

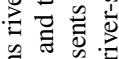

氙航㝴

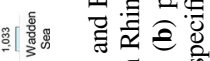

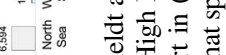

: 喜 悹

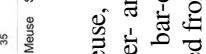

远芯

जि

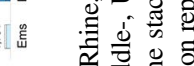

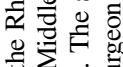

廿

के

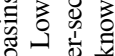

㱐索

ㄷㅎㅇ

过产

$8 \sum_{0} \sum_{0}$

त्)

ส

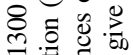

ปี

表余

ํํㄹ

के

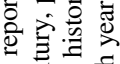

仓

造:

च

때융

氙 0

홓 홍 ส

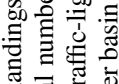

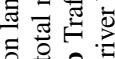

它宽

总的寻

预 売 专

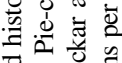

ฮే

的

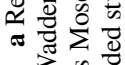

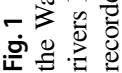


any risks to this critically endangered species (IUCN/SSC 2013). For example, the Rhine's use as a major European shipping lane potentially poses serious threats to sturgeons (shippropeller strikes, noise pollution, dredging, etc.).

A study of the historical spatiotemporal distribution and core habitat of sturgeons in the Rhine is an important starting point for evaluating the opportunities for their reintroduction. Historical fisheries data can be used as an indicator for long-term population distribution and abundance, with changes therein potentially linked to anthropogenic or climatological influences (Fortibuoni et al. 2017). Although historical fisheries data does not distinguish between the closely resembling A. sturio and A. oxyrinchus (Thieren and Van Neer 2016), historical biogeographical research can identify former core habitats and the species' seasonal distribution in the Rhine and adjacent catchments (Paaver 1999; Gessner et al. 2011; Williot and Castelnaud 2011; Spratte 2014; Lenders 2017). This study therefore addressed the following research questions, using historical sturgeon fisheries landings data and sales from the Netherlands, Germany, Belgium, Luxemburg, France and Switzerland:

1. What were the spatiotemporal distribution patterns of the now extirpated sturgeon populations in NW-Europe, with an emphasis on the Rhine river basin, but including the adjacent catchments of the Ems, Meuse and Scheldt rivers?

2. Which historical anthropogenic activities most likely dictated the extirpation of sturgeon populations in these river systems?

\section{Materials and methods}

\section{Study area}

The river Rhine is the 9th largest Eurasian river. Its drainage basin covers $185,260 \mathrm{~km}^{2}$, along a total length of $1230 \mathrm{~km}$, with an average discharge of about $2200 \mathrm{~m}^{3} / \mathrm{s}$ (Uehlinger et al. 2009) (Fig. 1). It flows to the north, from its origin in the Alps in Switzerland, through Germany, France and Luxemburg, to the lowlands in the Netherlands where it drains into the North Sea. The Rhine's mainstem is divided into the Alpine, High, Upper, Middle and Lower Rhine, based upon geomorphological characteristics (Uehlinger et al. 2009). Its largest tributaries are the Mosel, Main, Neckar and Aare rivers. In the Netherlands, the IJssel distributary of the Rhine drains c. 1/9 of the discharge to the north into the Wadden Sea. To the southwest, the Rhine's mainstem confluences with the river Meuse into a freshwater delta (from now on: Rhine-Meuse delta), an area renowned for its historical Atlantic salmon (Salmo salar), Allis shad (Alosa alosa), North Sea houting (Coregonus oxyrinchus) and sturgeon fisheries (Martens 1992). Downstream, the combined Rhine and Meuse rivers share a delta with the river Scheldt. Historically these rivers continuously shifted course (Berendsen and Stouthamer 2000). From the eighteenth century onwards, intensive river engineering that began upstream, shortened, and shaped these rivers into efficient shipping routes (Bloesch and Sieber 2003). Currently, the Rhine is a major European shipping lane with the Port of Rotterdam as its terminal, while the Rhine-Meuse-Scheldt delta is marked by huge storm surge barriers and strong land reclamation (Wolff et al. 1994; Steenhuis 2015). Because of the intricately interwoven geographical, hydrological and biogeographical connections between the river Rhine and its tributaries, the Meuse, Scheldt and Ems rivers, data were collected for all four of these river systems. 


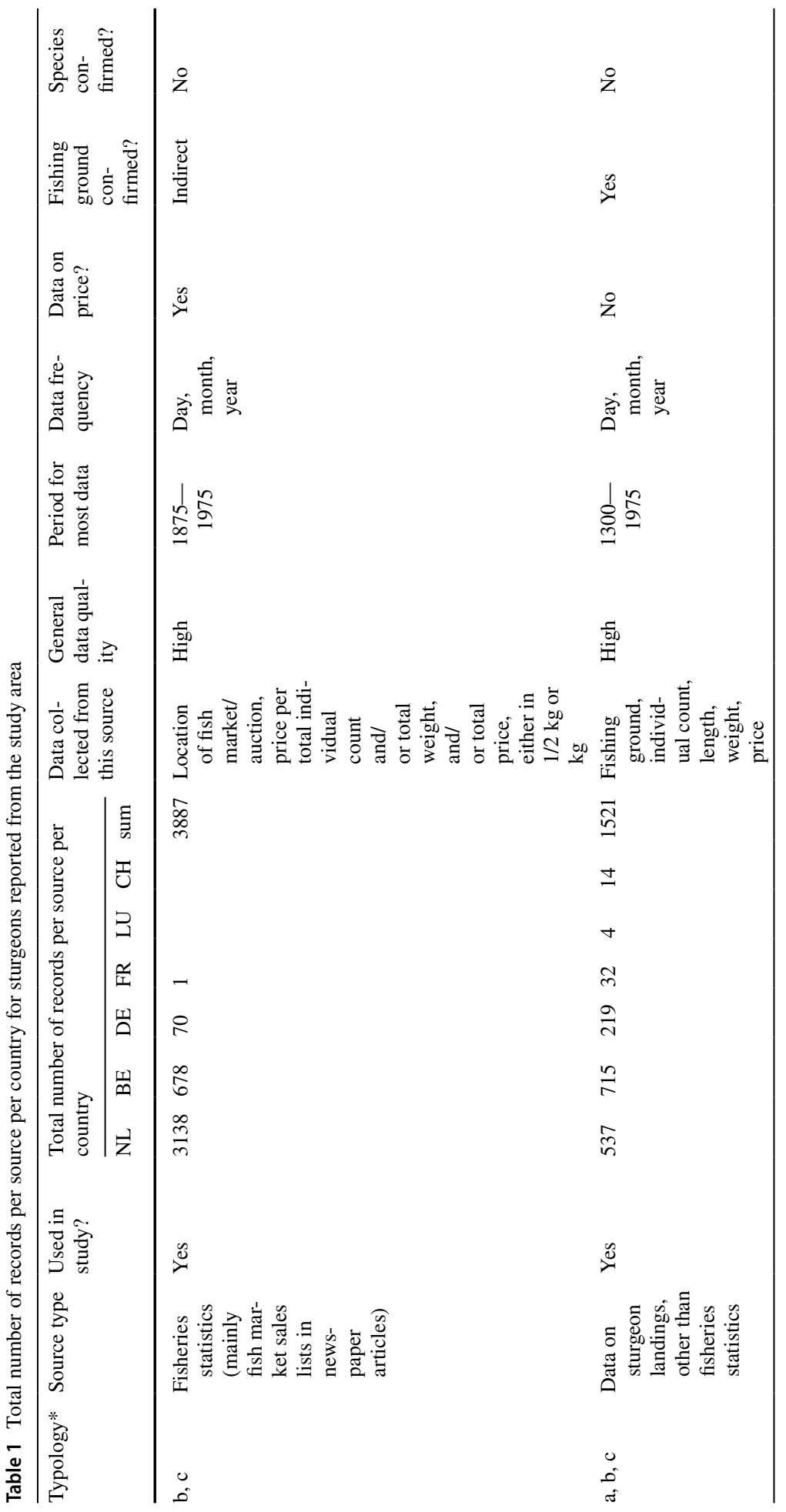




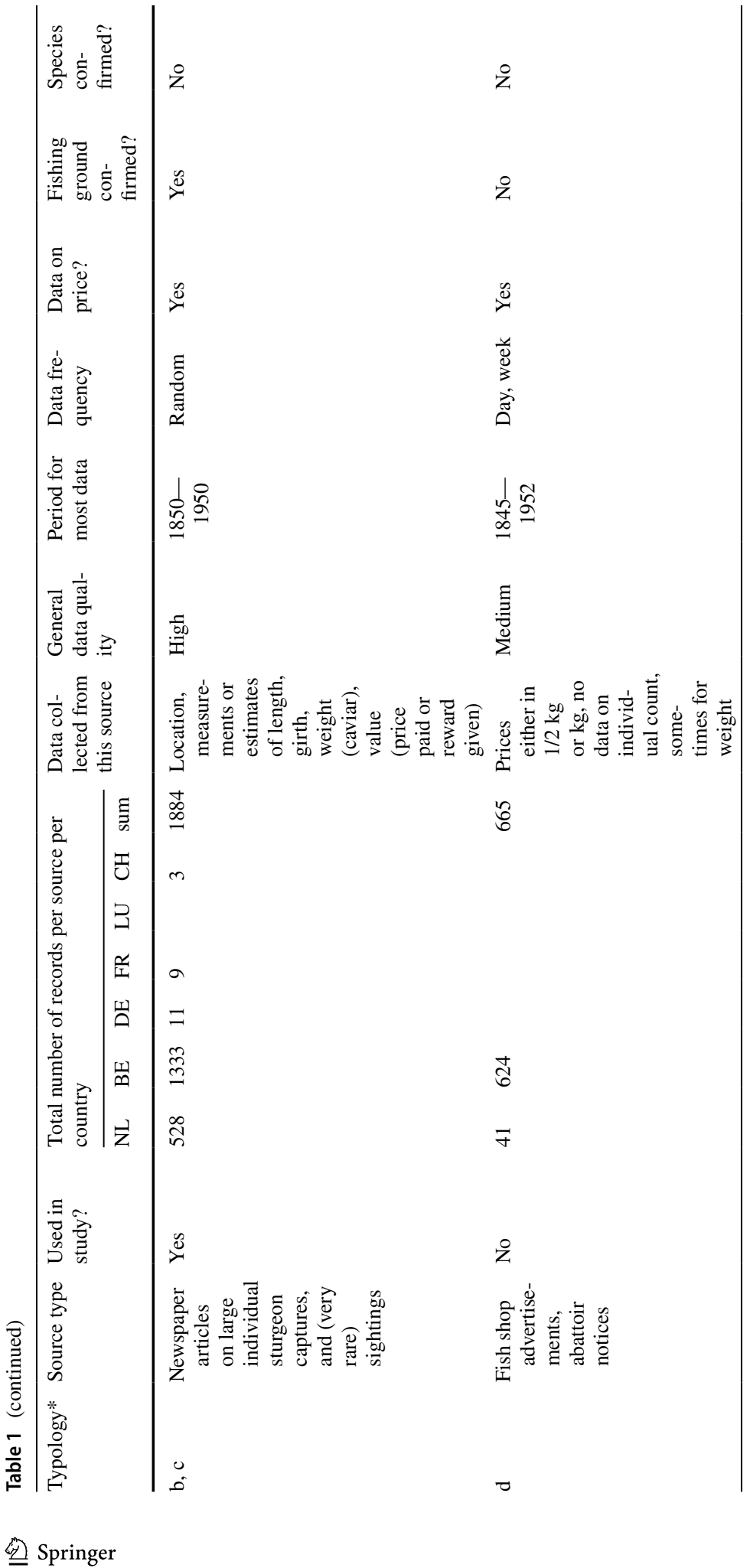




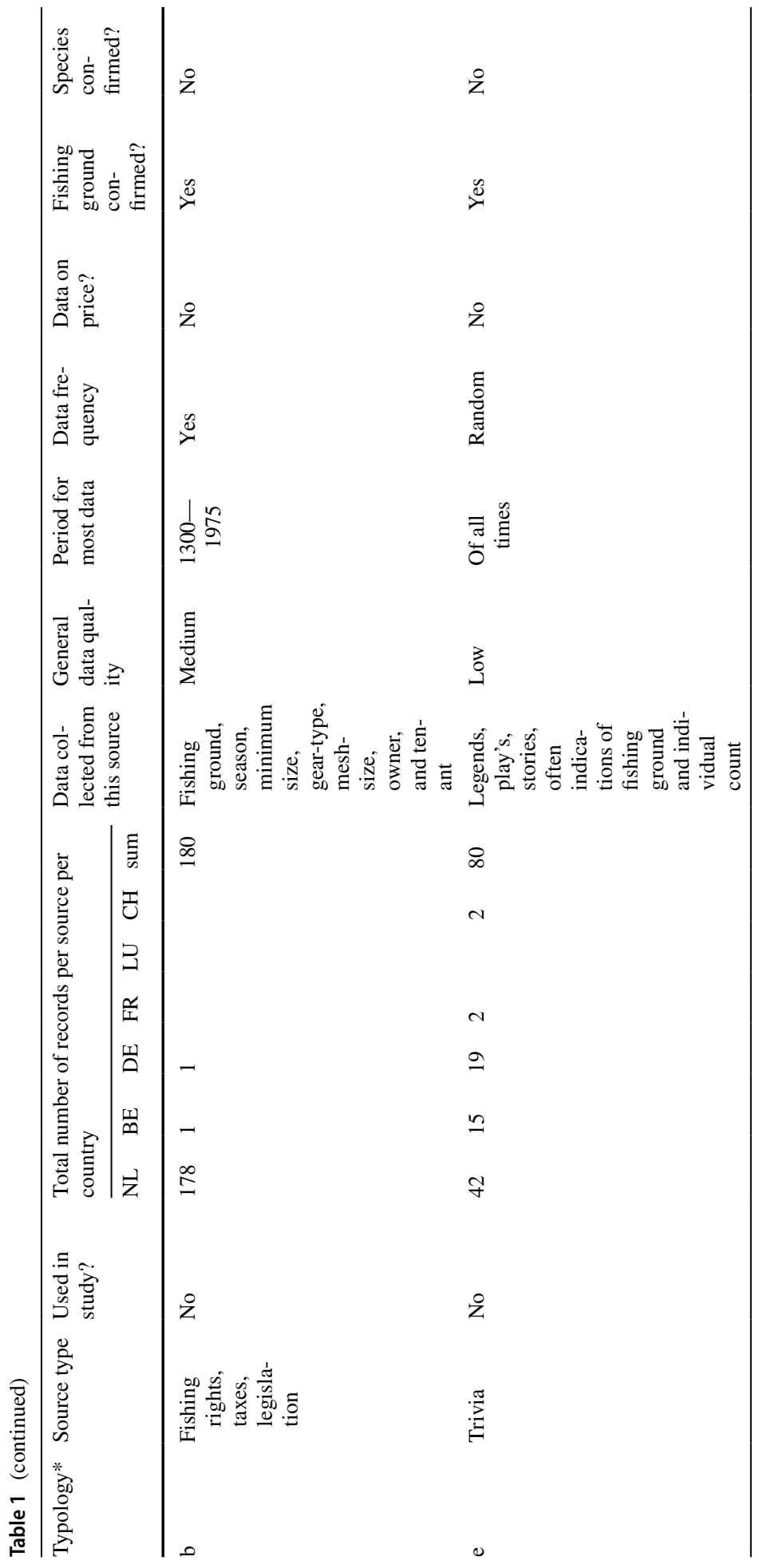




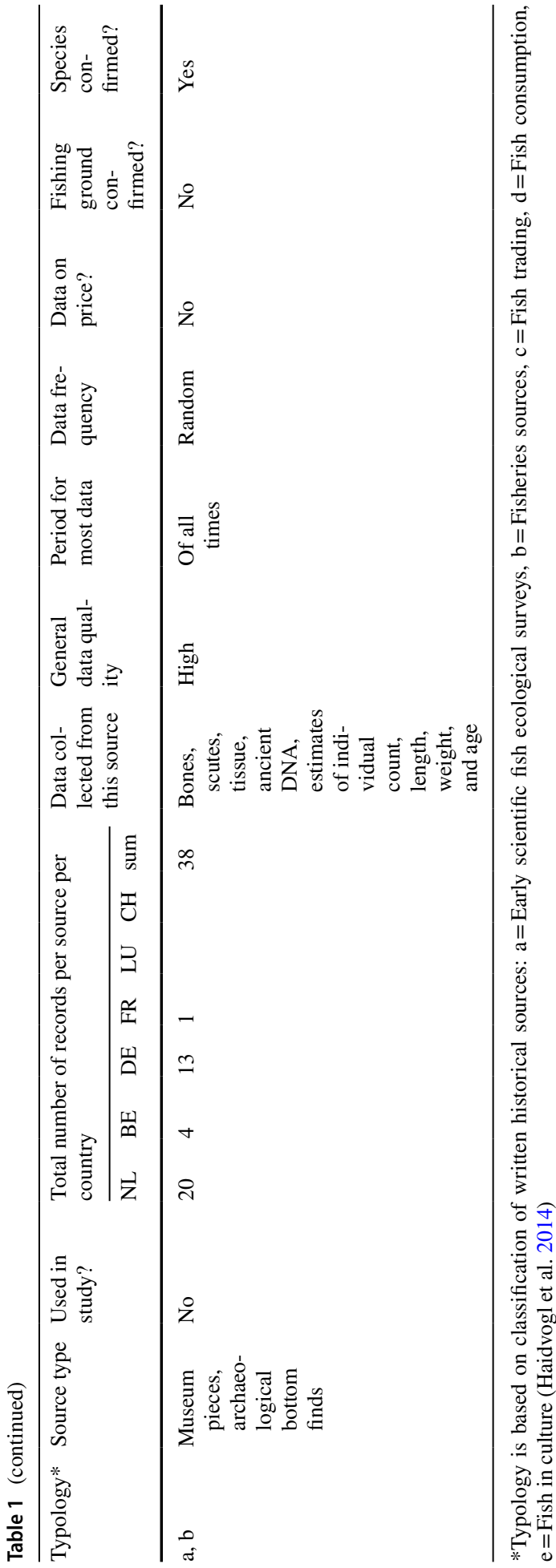




\section{Data collection}

Although there are several data series that span decades of sturgeon landings and sales for specific sites (De Jong et al. 1988; Martens 1992; Mohr 1952; Verhey 1949), there are no high-quality, long-term time series for the four river basins. We therefore collected data from multiple sources and collated a comprehensive dataset and time series. Data on fish consumption, references to fish in culture (legends, plays), and anecdotal data, were collected, but we focused on fish trading sources (especially fish market sales lists), fisheries sources, and early scientific fish ecological surveys (for typology, Haidvogl et al. 2014) (Table 1). Most data stems from the nineteenth century and later, but we have also tried to collect many older sources, because disregarding such older sources could lead to a serious content bias, leaving relevant long-term causes and processes out of the picture (Hoffman 1996). Historical sturgeon data, including archival sources and handwritten documents obtained from many different institutes and professions, were previously collected by Kinzelbach (1987, 1997), whose data was rechecked and added to our dataset. Google Scholar, Scopus and NSC ProQuest were searched, but contemporary reviewed literature yielded surprisingly little additional historical data for the study area. The database of the Global Biodiversity Information Facility (www. gbif.org) was downloaded (April 4, 2021) for Acipenser sturio and Acipenser oxyrinchus, and checked, which gave an additional 22 data entries. The dataset was further extended with data from historical books and handwritings, obtained through Google books and the universities acknowledged. A major contribution to the dataset was achieved by searching digitised newspaper-articles via www.delpher.nl (1618-2005, National Library of the Netherlands), www. belgicapress.be (1814-1970, Royal Library of Belgium), www.europeana.eu (1618-1980, European newspapers from 20 countries) and www.e-newspaperarchives.ch (1692-2018, Swiss National Library). These platforms yielded substantial quantitative data on fisheries statistics (individual counts, weights, and prices) for the period 1845-1953. The following search keywords were used in all platforms: sturgeon* (this includes the French 'esturgeon'), stör*, "Acipenser sturio", steur*; combined with Rijn, Rhin, Rhein, Maas, Meuse, Scheldt, Ems, Escaut. Searches for vernacular names and aberrant spellings like 'rombus' or 'fteur' yielded only 50 additional results. This search delivered nearly 150,000 hits that were sorted, filtered, and cleaned. Data on landings and sales could concern duplicates in the sense of 'repeated' records from different sources (mainly newspapers), and in the sense of 'summed' per week, month or year (mainly for fish auctions). Duplicate data were individually checked and, if applicable, marked in the dataset and filtered-out for data analysis. All data were sorted into predefined fields (such as year, month, week, numbers, weights, length, price per kg, per fish, source, URL). For sturgeon landings, and locations of fish auctions and markets, coordinates were found in historical maps provided by the Netherlands' Cadastre, Land Registry and Mapping Agency (Het Kadaster) via https://www.topotijdreis.nl, and verified with Google Maps https://maps.google.nl, adding an accuracy in km's when necessary (NA, 1, 2, 5, 10, 20, 50, $100,200 \mathrm{~km}$ ). The final dataset spans the 14th-twentieth centuries, it includes $>5000$ unique data entries on landings and sales of approximately 40,000 sturgeons for the study area and is deposited in the repository DANS-EASY under a CC BY-SA 4.0 license (Brevé et al. 2022; Table 1 for the overview). 


\section{Fisheries data analysis}

For spatiotemporal analysis, total numbers of sturgeon landings and sales (i.e. individual counts, locations, weights, and prices) were summarised per century, river (section) or sea (North Sea and Wadden Sea) and mapped in QGIS 3.16. Total numbers of sturgeons were summarised in separate timelines for the Rhine's delta, the river's mainstem, and for the sea. Seasonal distributions were analysed for all sturgeon numbers that were traceable to the month of catch. To obtain a proxy for the species local or regional abundance or scarcity, price developments on freshwater and sea fish markets were calculated by averaging yearly and 5-yearly prices, numbers and weights. This is a valid approach for socio-economically stable periods in history (so, excluding wars or economic crises), when the price of products is strongly linked to their availability (Lenders 2017; Lenders et al. 2016). Historical prices in Dutch Guilders were converted to equivalents in euros in 2016 via the consumer price index of the Institute of the Royal Netherlands Academy of Arts and Sciences (KNAW), based on Van Zanden (2013) (available for years 1450-2016); and from Belgian Francs to Euros in 2015 via the currency converter provided online http://www.historicalstatistics.org/Currencyconverter.html (Latest update 10 January 2016, available for years 1880-1950, except 1914-1920).

\section{Results}

\section{Spatiotemporal distributions of sturgeon landings and sales}

The historical distribution of sturgeons in the four river systems appears to be confined to the estuaries, the (freshwater) delta areas and the Rhine river's mainstem. Clearly, fewer sturgeons were reported for the tributary rivers, the High Rhine, and the Ems, Meuse, and Scheldt rivers. Most data were obtained from fisheries and fish auctions in the RhineMeuse delta in the Netherlands (27,714 specimens: $98 \%$ of all sturgeon capture reports from the river Rhine) (Fig. 1a). For the Rhine, the number of reported sturgeons diminished immediately upstream from this area. In total $590(2 \%)$ sturgeons were reported from the Rhine's mainstem in the Netherlands, Germany, France, Luxemburg, and Switzerland; of which 319 originated from the Lower, Middle, Upper and High Rhine, and 70 from the main tributaries Mosel, Main, Neckar and Aare, while all other (of the thirty-three) Rhine tributaries seldom yielded sturgeons.

From the Wadden Sea and the estuaries of the therein debouching rivers, sturgeons were only occasionally reported, yet these reports represent high numbers of fish. For example, 237 sturgeons in 1869 and 80 in 1870 were landed and sold at one seaport situated in the river Lauwers estuary; in 1896, 672 sturgeons were landed at hamlets in the north of the Netherlands. No weights or prices were mentioned. Because, in general, adult sturgeons were usually weighed, priced, and taxed, the sturgeons mentioned may have concerned smaller/younger specimens. From the river Ems, 40 sturgeons were reported, which is much lower than the total of 1704 sturgeons captured in the Ems-estuary (named: Dollard). From the small river Lauwers-estuary and its tributaries, 14 mature sturgeons were reported between June and July. Although, according to anecdotal information, large numbers of sturgeons were captured in the Rhine's IJssel distributary and its freshwater delta in the Zuiderzee pre-1700 (Ennema 1946), only a total of 121 sturgeons were reported from this region between 1321 and 1932 . 
For the North Sea, most sturgeon reports were obtained from the late 19th and early twentieth centuries. The decreasing river catches and increasing marine catches resulted in a yearly marine harvest in the Netherlands that, by 1910, exceeded that from the RhineMeuse delta. Belgian and Dutch sea-fisheries reported a total catch of 1192 and 5402 sturgeons respectively (see also Fig. 1a). Yields of trawl fisheries were registered by the Dutch and Belgian governments in annual reports. For the Netherlands the series spans 16 years (Hoek, 1894; Redeke, 1915), for Belgium 24 years (Zeevisscherij 1912, 1936). These Belgian statistics specify propulsion type, seaport, and fishing ground for sturgeon harvests. For this period, almost $100 \%$ of sturgeons marketed in Belgium were landed by steam trawlers (not sail), sold at Belgium's main fish market in Oostende, and caught at both nearby fishing grounds (e.g. the Belgian coast and the English Channel), as well as from distant areas (e.g. the Bay of Biscay, Portugal, and the northern North Sea).

Although there are many data gaps in the timeline (Fig. 2), the pattern for the 18thtwentieth century, and historical reports (e.g. Hoek, 1910), suggests that the sturgeon's decline started in the late nineteenth century, around 1885. This was followed by approximately 35 years of rapid population decrease, until c. 1920 when the species effectively vanished from the river systems, followed by another 30-50 years of sporadic landings until the species total disappearance. The last sturgeon captured in the river Rhine dates from 1952, for the North Sea the year is 1974 (Fig. 1b).

\section{Seasonal patterns}

Seasonal analyses of summed-up catches of mature sturgeons over the years, showed a strong pattern. Catches of riverine sturgeon increased from March onwards, with a dominant peak in June, after which catches declined again until August (Fig. 3). Although there are very rare reports of sturgeon occurrences during winter months, i.e. one sighting in the Meuse in 1890 and four from the river Aare in 1895, in general, the mature spawners left the rivers between September and March. Catches ranged from 0 to 2500 specimens per month. Marine catches, that started around 1885, showed far less seasonal fluctuation, ranging from 50 to 150 per month, with a dip in the number of catches between May and September (Fig. 3). Maturity was based on the sturgeons' size (see also the mean weight in Fig. 4b).

\section{Market developments}

Remarkably, the dataset unveils a substantial trade in sturgeons from the Netherlands to Belgium. As early as the fifteenth century, fisheries and fish auctions from the RhineMeuse delta transported salmon, Allis shad and sturgeon (salted or pickled in barrels) towards Belgian and French cities (Leuven, Gent, Antwerp, Brussels, Liège, Paris, etc.). This was mentioned by, for example, Hoek (1910) and Martens (1992), and substantiated in this study by the collection of hundreds of newspaper articles from Brussels' 'Poissonneries' (fish shops), advertising sales of sturgeon 'from Holland' (Brevé et al. 2022). Between 1742 and 1775, different fisheries delivered their harvests to the region's central Geertruidenberg fish auction, which sold on average 468 sturgeons per year from the Rhine-Meuse delta, while between 1895-1900 all fish auctions in the area reported a combined average of 521 sturgeon sales per year (Fig. 2a). Although exceptionally big sturgeons were landed from the sea (the largest on record had a total length of $>5 \mathrm{~m}$ and weighed $350 \mathrm{~kg}$ (Brevé 
a

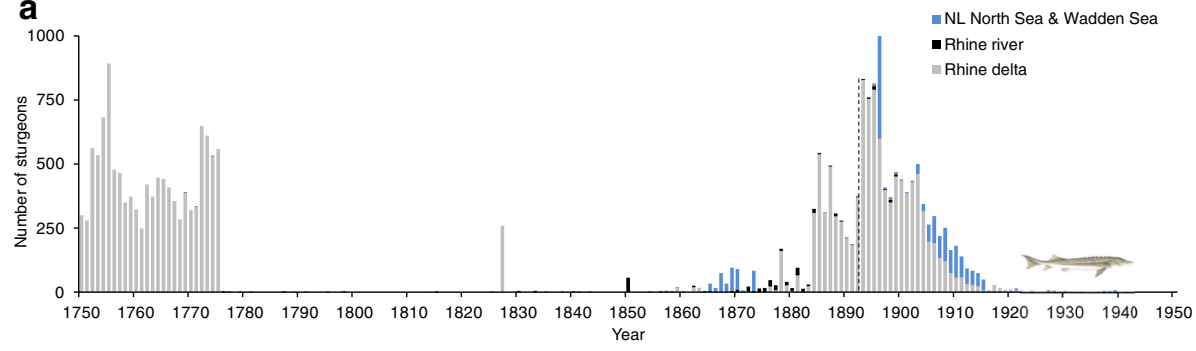

b
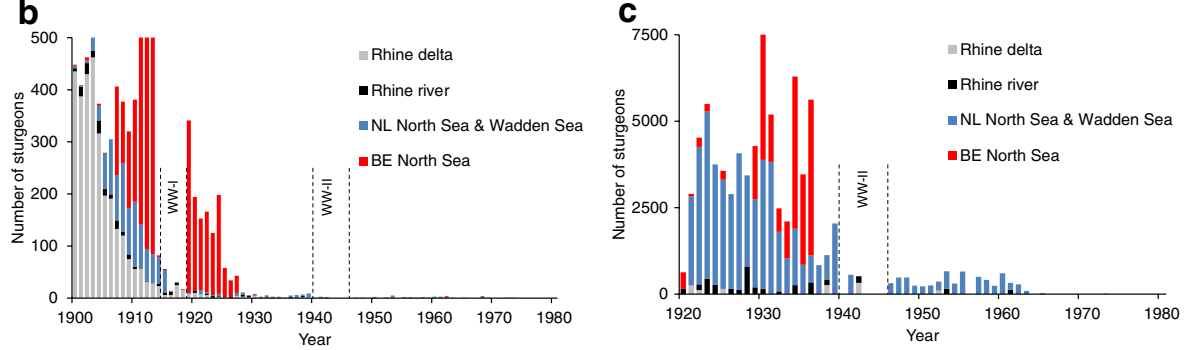

Fig. 2 a Total numbers of reported sturgeon landings and sales per year between 1300 and 2000 from the river Rhine (black), Rhine-Meuse delta (grey), North Sea \& Wadden Sea (blue). Excluded are data for the Ems, Scheldt and Meuse rivers. The 'peak' between 1742 and 1775 (shown in this graph from 1750 onwards) originates from the region's central, collective fish auction (Geertruidenberg) for six different fisheries in the Rhine-Meuse delta (Martens, 1992). Data between 1875 and 1931 originate mainly from other central fish auctions (Hardinxveld, Kralingsche Veer) and different fisheries in this area. Dotted line: start of the North Sea steam trawl fisheries. b Total numbers of sturgeons per year between 1900 and 1980 from the river (black) and all delta areas (grey), North Sea and Wadden Sea for the Netherlands (NL Sea, blue) and Belgium (BE Sea, red). c Idem, between 1920 and 1980, in total weights. N.B. From 1920 onwards fish auctions reported sturgeons in weights. Sometimes, both the numbers and total weights are available, enabling an estimate of the average weight of individual fish. Dotted lines: beginning and end of World Wars I and II

Fig. 3 Summed catches over the year (in the period 1300-2000) of sturgeons from the Rhine river basin ( $n=5656$, grey line), and from the North Sea for The Netherlands $(n=1103$, black dashed line)

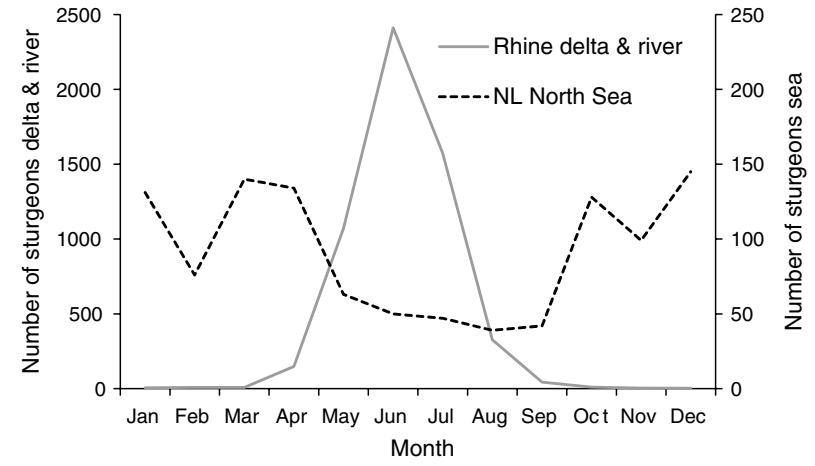



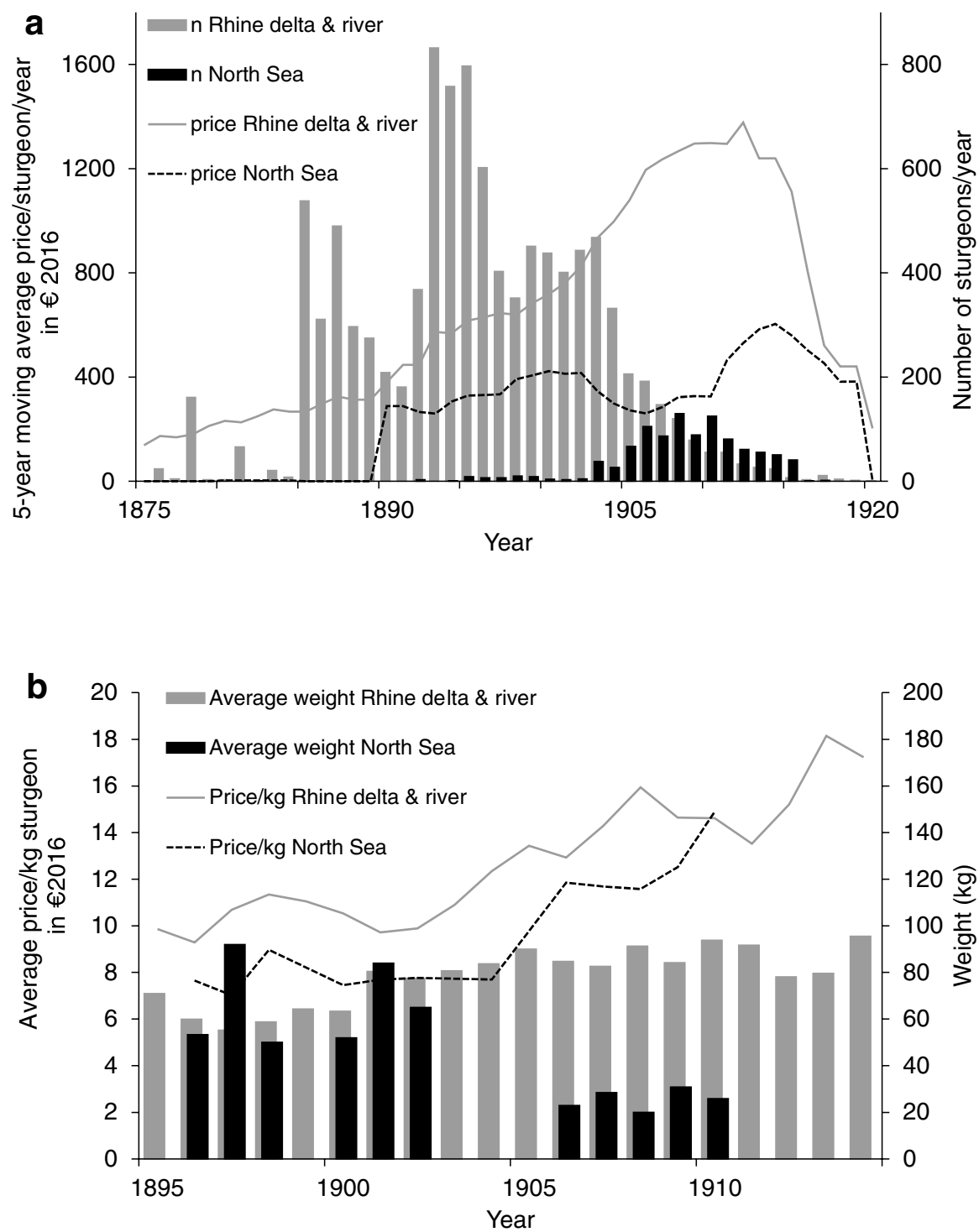

Fig. 4 Price development for sturgeon at Dutch fish auctions, selling sturgeons from the river Rhine and North Sea. a 5-year moving averages in price per sturgeon between 1875 and 1920 and the total number sold per year (n/year). b Average price/kg and average weight per sturgeon between 1895 and 1914. Grey lines and symbols = sturgeons caught in the delta \& river; black (dashed line) $=$ sturgeons caught at sea. c Average price per sturgeon in relation to the total number of sold sturgeons per year (n/year) between 1895 and 1914. Original prices in Dutch guilders were converted to 2016 Euros $(€)$. For the Rhine river the exponential relationship is statistically significant $\left(y=1408 \cdot \mathrm{e}^{-0.00133 x} ; \mathrm{R}^{2}=0.75, \mathrm{p}=<.0001, \mathrm{n}=20\right)$, for the North Sea catches there is no statistically significant relationship $\left(R^{2}=0.06, p=0.298, n=19\right)$ 


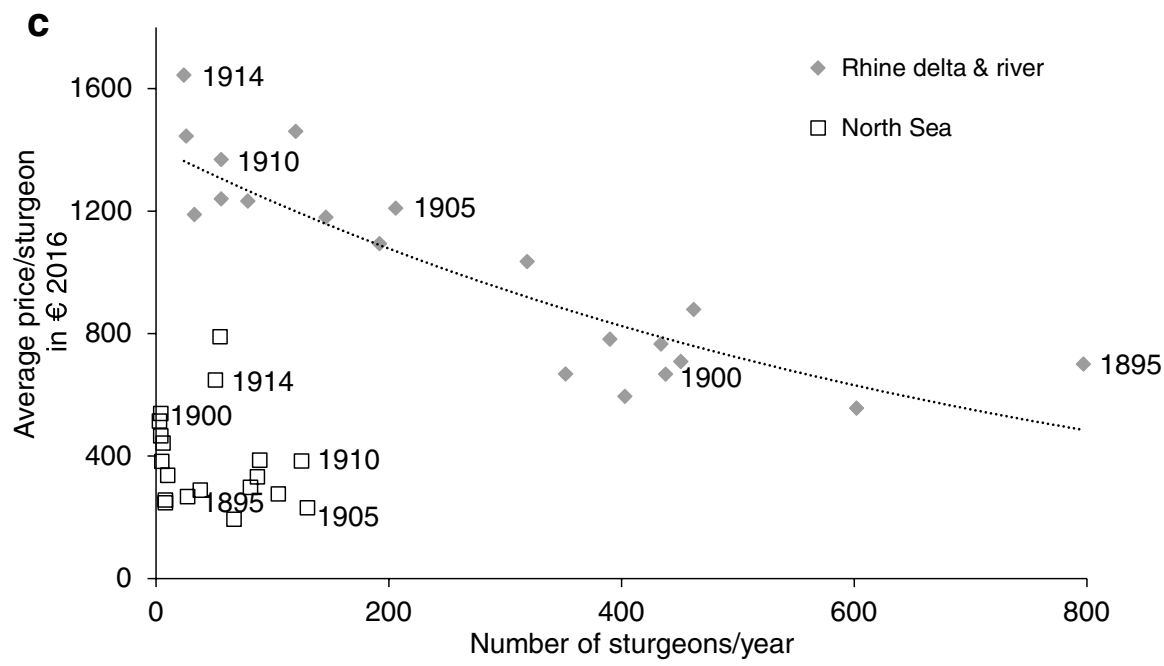

Fig. 4 (continued)

et al. 2022)), in general sturgeons from the sea were smaller than those harvested from the Rhine-Meuse delta (Fig. 4b). Figure $4 \mathrm{~b}$ also provides some evidence of a diachronic change in sturgeon weights between 1895 and 1914. During this period, the average individual weight for sturgeons sold at fish auctions in the Rhine-Meuse delta increased from 60 to $90 \mathrm{~kg}$, whilst numbers dropped by $90 \%$. Simultaneously, sturgeons harvested from the sea decreased in average weight from 60 to $20 \mathrm{~kg}$, whilst their numbers increased, after which these harvests also collapsed (Fig. 4b). Between 1895 and 1914, a sturgeon's value in the Netherlands, taken from the Rhine-Meuse delta, almost doubled from an equivalent of circa 10 euro per kg to 18 euro per kg (Fig. 4a, b). The largest sturgeons fetched the highest prices, even up to an equivalent of $>1000$ euro per fish (Fig. 4c). Prices continued to increase at a time when sturgeons became scarce between 1905 and 1914 (Fig. 4a). The data suggests that prices were influenced by World-War I when the Netherlands were neutral, while Belgium, Germany and so many other countries were at war. The war caused a decreasing demand, which led to prices dropping heavily from 1914 onwards, making clear that it was mainly an export market that drove Dutch Rhine and North Sea sturgeon fisheries.

\section{Discussion}

This study aims to identify the historical spatiotemporal distributions and core reproductive habitats of sturgeons from the river Rhine and neighbouring basins of the Ems-Dollard, Meuse and Scheldt rivers, as well as the principal factors behind the sturgeon's population decline and ultimate extirpation. From the Late Middle Ages onwards, sturgeons were claimed by, and given to, the central authorities of ecclesiastical and secular powers (Blackstone 1830). Sturgeons were a welcome food source, and of general interest (put on display) to the public because of their size (Boddeke 1971). Hence sturgeons were often numerically recorded, and 
taxed (Martens 1992), yielding high prices in the Netherlands, Belgium, Germany, and other North Sea countries (Hoek 1900; Zeevisscherij 1925; Mohr 1952). This strong interest suggests that sturgeons will have been fished for, wherever they occurred.

\section{Historical data, use and limitations}

A large dataset could be collected from historical books, handwritten notes, annual fisheries statistics and newspapers that included exceptional captures (big fish), fish shop advertisements, and frequent fisheries statistics for local or regional markets and auctions (Brevé et al. 2022). Yet there are inevitably numerous data gaps and probably many historical statistical records have been lost. Searching digital (newspaper) archives is laborious, despite the availability of ever better digital filtering techniques (Van Erp et al. 2018), and it is inevitable that some of the data is not found because some sources are still insufficiently accessible. Many libraries were damaged during the second World War (Van der Hoeven and Van Albada 1996). Moreover, fewer catch records were obtained from small-scale fisheries than for fish expedited straight to markets abroad (Antwerp, Brussels) (Hoek 1910). Catch- or market data could also have been underreported to avoid taxes (Haidvogl et al. 2014); and in general, most reports concern adult fish, not the younger sturgeons. Although most data collected originates from post 1850 , the data collated from pre- 1850 sources comprises $>300$ verified records. These long-term data also help in avoiding bias, since they offer insight into potentially relevant ecological and economical processes that may have influenced - in this case-sturgeon population developments. Thus, the findings of this study are supported by several lines of evidence, from spatiotemporal distributions and developments in numbers, weights and prices, which substantiate the identification and seasonality of the species' reproductive grounds; and from historical anthropogenic pressures affecting the historical sturgeon population in NW-Europe.

\section{Reproduction grounds and season}

One main finding is that a surprisingly high number of sturgeons were reported from the Rhine-Meuse delta in the Netherlands (c. 28,000 or $98 \%$ of the total river Rhine's catch). This is in strong contrast to the fraction of sturgeon landings and sales (c. 600 specimens) reported from all upstream river reaches, including the tributary rivers in Germany, Luxemburg, France, and Switzerland. This geographical distribution pattern is in accordance with previous reports for the Rhine and for other river basins, like the river Elbe where most sturgeons were also reported from the river's mouth (Kinzelbach 1987, 1997; Holčík et al. 1989). However, this distribution in data raises the question as to whether the sturgeons' dominant occurrences in the Rhine-Meuse delta can be explained by their biology and ecology, an important part of their life cycle being spent in estuaries/delta areas (see e.g. Acolas et al. 2011), or by a strong regional fisheries effort, or by both. Answering this question is critical in identifying which river sections were key to sturgeons, because this is of paramount importance for sturgeon habitat restoration and protection.

\section{Spawning season and main pathways upstream}

This study shows that the sturgeons' spawning run peaked in June, around the longest day, at the start of the summer season when the Rhine is still fed by snowmelt from the Alps (Uehlinger et al. 2009). Notably, rivers fed merely by rain have a decreased discharge 
during dry summer months (e.g. rivers Meuse, Scheldt, and Ems), whilst rivers fed by rain and snowmelt (like the river Rhine) have a more continuous river discharge, even during dry summer months. The influence of snow melt is therefore discernible to the delta (Uehlinger et al. 2009) and the strongest freshwater current may have lured sturgeons towards the Rhine, instead of to the Meuse, Scheldt, and Ems. The sturgeons clearly preferred certain river systems and sections. Rare captures of mature sturgeons occurred in the tiny Lauwers river system and in the smallest of tributaries of the river Scheldt. These fish most probably strayed into these minor water courses, as these provide no suitable spawning habitat. There is also proof of occasional occurrences in the river Meuse near the Belgian cities of Visé and Liège, mostly before 1850 when the population was still at an average level, and often during and after rainfall (Brevé et al., 2022). Supposedly, these fish used the risen water levels to enter the Meuse from the Rhine-Meuse delta and explored this river that normally carries much less water than the Rhine. These findings demonstrate that mature sturgeons could occur in all parts of the four river systems, even in the capillaries, however, the largest numbers occurred in the (largest) currents and delta areas.

\section{Spawning grounds}

Because of the sturgeon's abundance in the Rhine-Meuse delta, it was suggested by several authors that this particular area was used for spawning (Deelder and Huussen Jr. 1973). Yet Hoek, the first prominent Dutch fisheries biologist, declared that no spawning activity was observed and suggested that this occurred further upstream in the deep sections of the river (Hoek 1910). In 1949, Verhey writes that the entrepreneur of the 'Nieuwe Merwede' fisheries (salmon-seine fisheries located in the most upstream part of the Rhine-Meuse delta) had never seen a spent sturgeon. Verhey (1949) observed that sturgeons at this location were mainly captured during ebb periods in the deepest part of the delta, when the strongest and deepest currents occur. Because of this he suggested that sturgeons at this site were on their spawning run, moving further upstream. Current knowledge on sturgeons' biological cycles and morphological insight in the area seems to corroborate these findings. Both the Rhine and Meuse rivers confluence in this freshwater delta and continuously deposit part of their silty and muddy bedload. Continuous sedimentation, creating environments of swampy creeks and islands provides no suitable spawning habitat for the European sturgeon, because this species requires deep, oxygenated, heterogenous gravel beds (Jego et al. 2009). Moreover, the influx of brackish waters in the Rhine-Meuse delta would hamper the survival of larvae and young-of-the-year sturgeons that naturally move downstream and are unable to osmo-regulate in their first year (Acolas et al. 2011). The area seems unsuitable for Atlantic sturgeon spawners as well, which prefer gravel for ease of attachment of the adhesive eggs and for the interstitial spaces providing refuge for the larvae, although they may use sandier or even siltier substrates, but not pure mud (Bain et al. 2000; Sulak et al. 2016). It thus becomes apparent that sturgeons, together with Atlantic salmon, Allis shad, and other diadromous fish aggregated 'en masse' within these funnel-shaped, shallow grounds (Martens 1992), but none of these species spawned in the Rhine-Meuse delta (Reekers 1916; Huijbregt 1984; Martens 1992).

As the spawning grounds were most probably further upstream, the question remains: how far upstream? Both sturgeon species can undertake long range spawning migrations. European sturgeons can even cover over 1000 river kms (refs in Holčík 1989), with their migration distance being positively correlated with river discharge (Holčík et al. 1989). Sturgeons from the Rhine were occasionally reported at Strasbourg (Upper Rhine) 
(Baldner 1666), but only exceptionally further upstream at Basel and Bern in Switzerland (High Rhine). This consistent pattern was previously reported by several authors (Hartmann 1827; Brandt and Ratzeburg 1833; Leuthner 1877) and written down as early as in 1625: "Their migrations in the Rhine rarely extend beyond the lower Rhine, which is why its appearance in the middle Rhine is already rare. The sturgeon rises to Basel even more rarely and only as an exception." (Leuthner 1877). This implies that sturgeons normally occurred between Bingen (river km 530) and the Port of Rotterdam (river km 1026), i.e. at a maximum distance of c. $500 \mathrm{~km}$ from the river mouth. Yet, mature sturgeons probably did not need to move far into Germany, as approximately $100 \mathrm{~km}$ in the upstream direction in the Lower Rhine in Nord Rhine-Westphalia (Germany) sturgeons encountered an abundance of deep, highly oxygenated, heterogenous gravel beds in strong currents, ideal spawning habitat for European sturgeons. Possibly, Atlantic sturgeons would spawn somewhat closer to the delta than European sturgeons, because of their preference for somewhat smaller sized substrates, but this cannot be substantiated from the collected dataset as no distinction could be made between the two species. This is consistent with observations that most mature sturgeons did not move far into Germany, something that was previously attested by Hoek (1910), Verhey (1949) and Kinzelbach (1987). Considering that the sturgeon's spawning run only lasted a couple of months, whereafter they left the river empty between September and March, and considering the energy costs and duration of up- and downstream migration over $1000 \mathrm{kms}$, it seems plausible that most sturgeons didn't move that far upstream. In comparison, most of the 27 mapped historical spawning sites in the Garonne and Dordogne rivers were located within 200-270 km from the Gironde estuary (Bismuth 2019; Jego et al. 2002). In the river Elbe, sturgeons were found to spawn up to $400 \mathrm{kms}$ upstream, but the main spawning areas were not that far upstream. We cite from (Williot et al. 2011): "In the river Elbe the main spawning sites in the nineteenth century were in the lower part of the river between Brunsbuttel-only approximately $40 \mathrm{rkm}$-and Hamburg at 110 rkm (Quantz 1903)."

\section{Nursery grounds}

As nursery grounds are naturally located downstream from the spawning grounds (Acolas et al. 2011), this suggests that the freshwater Rhine-Meuse delta in the Netherlands, and the IJssel distributary in the Wadden Sea (former Zuiderzee) would have been an important habitat for young-of-the-year sturgeons. There are indeed indications of large numbers (hundreds) of sturgeons captured over a period of weeks in these areas (Ennema 1946; Brevé et al. 2022), which needs further study.

\section{Historical anthropogenic pressures}

The decline of the Rhine's diadromous fishes is generally explained by a strong deterioration and loss of spawning and nursery habitat, caused by reduced water quality and extensive river-reconstruction, as well as overfishing (de Groot 2002; van Emmerik. 2004; Nemitz 2010). In salmon, the decline could have started as early as during Early Modern Times (post 1500 AD), caused by the historical rise of water power in tributary rivers (Lenders et al. 2016). In sturgeon, the decline seems to have started at the earliest by the end of the eighteenth century (Lenders 2017), which was confirmed by this present study. This raises the question: which anthropogenic activities impacted the sturgeons most, when and where? 


\section{Fisheries in the Rhine-Meuse delta}

Historical information shows the existence of a thriving fisheries community in the RhineMeuse delta as early as 1421, which continued for centuries, as the area is well suited to large-scale fisheries for diadromous fish (Verhey 1949; Deelder and Huussen Jr. 1973; Martens 1992). Sturgeons were targeted with driftnets and other types of strong fishing gear (Brehm 1900; Hoek 1910; Mohr 1952). Sturgeons became trapped in fykes and entangled in seine nets used in salmon and shad fisheries (Brevé et al. 2022; Brehm 1900). From c. 1870 onwards, fisheries in the Rhine-Meuse delta became industrialised, simultaneously with a reasonably well-developed fish auction system (Hoek 1910; Martens 1992), which is mirrored in the increased sales notifications from multiple markets in the Rhine-Meuse delta (aggregated in Fig. 4). This increase could partially be due to an underestimation of the true sales by under reporting in older sources, as by 1885 sturgeon yields were already in decline, which was described by Hoek (1910). When the actual decline began remains unclear, due to a substantial lack of older data. In 1908, fishers in the Rhine-Meuse delta tried to make their business more profitable by scaling up and further increasing mechanisation, to improve efficiency, which led to a short-lived increase in salmon and shad harvests, especially during World-War I. Their partnership 'Nieuwe Merwede' continued until 1931, after which they, and most other large seine fisheries, were forced to close their business due to a substantial decline in yields (Verhey 1949).

\section{Upstream fisheries}

In upstream river sections, sturgeons have historically most probably always been rarer than in the downstream reaches (Quantz 1903; Williot et al. 2011). Although upstream fisheries may have been unevenly distributed, it is unlikely that German sturgeon captures from the nineteenth and twentieth centuries were left completely unreported. Several indications for this exist. For instance, German fisheries in the Rhine successfully targeted salmon, and their sturgeon harvests were much lower than in the Netherlands (Bürger 1926; Böcking 1988). This finding is further supported by the fact that in 1886 , a salmon treaty was signed between the German, Swiss, Luxembourg and Dutch governments (Boetticher 1886). The reason for this treaty was a general decline in salmon yields. It prohibited the use of fishing methods which would block more than half of the breadth of the watercourse, prescribed closed seasons, minimum fish size, etc. However, this treaty did not consider sturgeons. The scarcity of sturgeon captures was confirmed by a study by colleagues from the Rheinische Fischerei Verband, who stress that that salmon fisheries were abundant in the mouths of tributary rivers (Sieg, Lippe, Mosel, etc.), yet hardly any sturgeons were recorded (Nemitz 2010). Thus, all available sources point to a rather limited abundance of sturgeons in upstream fisheries, which cannot be exclusively explained by a lack of such fisheries in either the Lower, Middle, Upper or High Rhine in Germany, France, Luxemburg or Switzerland.

\section{Fisheries at sea}

As sturgeons spend most of their life at sea, and only migrate back into their spawning rivers at an advanced age, and for mature females only every 3-5 years (Bain 1997; Acolas et al. 2011), the risk of rapidly overfishing a population at sea is greater than in the 
river. River fisheries harvested a part of the mature spawners, but only seasonally, mostly in June when the sturgeon's spawning run peaked (Fig. 3). Between 1895 and 1914, freshwater fish auctions sold increasingly heavier sturgeons, and landed numbers further collapsed. In contrast, sturgeon harvests from the sea decreased in average weight during the same period. The rise in harvests from the North Sea fleet coincides with the introduction of steam engines to the fishery and the replacement of sail trawlers. Steam trawl fisheries developed in England and Scotland and expanded by the end of the nineteenth century. The construction of a steam trawler fleet in Britain was rapidly followed (with purchases in England) by Belgium (1884), Germany (1885), the Netherlands (1892), France (1894), and other sea faring countries (Sahrhage and Lundbeck 2012). Compared to sail trawlers, steam trawlers towed larger gear, moved faster, fished in more distant waters, further offshore and in deeper grounds, and for longer periods (less influenced by the wind) (Engelhard 2008). Consequently, the rise in steam trawlers impacted the marine populations year-round, targeting sturgeons of all age classes, including populations from multiple rivers debouching in the northeast Atlantic (possibly also from the Thames, Severn, Elbe, Loire-Allier, Gironde, etc.) (Demoll and Maier 1940; Engelhard 2008; Gessner et al. 2011).

\section{River engineering}

Considering the natural distribution of sturgeon's reproductive areas in the lower courses of the river's mainstem, it is unlikely that sturgeon recruitment was fully limited by the pressure of deteriorating habitats in the tributary rivers, or upstream in the river's mainstem of the High- or Alpine Rhine in Germany, France or Switzerland. After the start of the Tulla corrections (straightening of the Rhine from 1814 onwards), undoubtedly a lot of fine-grained material was washed out in the High and Upper Rhine, possibly deposited on pebble/boulder substrate further downstream and deteriorating spawning and nursery habitat. Additionally, sand and gravel was dredged away for construction works. In the Garonne and Dordogne rivers dredging of gravel destroyed multiple historical sturgeon spawning grounds, an activity which is now banned (Williot and Castelnaud 2011). However, even at present, and although it is partially impacted by the shipping lane, there is ample spawning habitat left in the Lower Rhine in Germany (Staas 2017). Another anthropogenic stressor, the building of huge storm surge barriers in the Netherlands (in 1932 and 1970; Steenhuis 2015) affected all diadromous fish populations. Interestingly, these dams only appeared after sturgeons had already effectively vanished from the Rhine River system, which was around 1920. Moreover, at present, the river's mainstem and its broad, deep gravel beds are still partially intact and in open connection to the North Sea over a length of approximately $850 \mathrm{~km}$. Therefore, habitat deterioration and loss alone cannot fully explain the sturgeon's extirpation from the Rhine. Loss of suitable spawning and nursery habitat in concert with intensified fisheries in the river and, especially, sea fisheries can.

\section{Implications for sturgeon population restoration}

This study provides evidence that the sturgeon's decline in NW-Europe at the end of the nineteenth century was impacted by reproductive habitat deterioration, industrialised fisheries in the delta, and strongly increased catches by marine steam trawl fisheries. The results from this historical study suggest that the minimum requirement to make the river Rhine suitable for sustaining a viable sturgeon population, should be for reproductive 
habitat restoration in the Rhine-Meuse delta in the Netherlands, and in the Lower Rhine in Germany, and not in upstream reaches or tributaries in Germany, Luxemburg, France or Switzerland. It is highly recommended to study the potential for this habitat restoration under the current conditions and anthropogenic influences, further drawing on lessons from the past.

Acknowledgements The authors would like to thank Ria Derkx, Annemie Kersten and Joke Webbink from Wageningen University \& Research - Library; Jaap Quak, Remko Verspui and Connie Kolfschoten from Sportvisserij Nederland; Herman van Dam from Gemeente Amsterdam Stadsarchief; and the libraries of Radboud University Nijmegen, the Flanders Marine Institute, and the Royal Netherlands Institute for Sea Research for their aid collecting the data; Mark van Leeuwen for his artwork; Igor Spierts and Arjan van Doorn for their comments on a first draft; Irene Verhagen and Hilda van der Pol from Wageningen University \& Research's Research Data Management group for their aid in storing the data in a repository; Miranda Maybank for English language editing.

Author contributions NB developed the research idea, collected and managed data, performed analyses and conceived maps and graphs; TvT and RL collected additional data. AB and EW co-authored the manuscript. $\mathrm{TM}, \mathrm{LN}$ and RL also co-authored and led the writing of the manuscript.

Funding The study did not receive any specific grant from funding agencies in the public, commercial, or not-for-profit sectors.

Availability of data and material The datasets generated and analysed during the current study are available in a DANS Easy repository (Brevé et al. 2022).

Code availability Not applicable.

\section{Declarations}

Conflict of interest The authors declare that they have no conflict of interest.

Ethical approval There is no need for ethics approval to develop this study.

Consent to participate All authors consent to their participation in this study.

Consent for publication The authors consent to the publication of this study by Springer.

Open Access This article is licensed under a Creative Commons Attribution 4.0 International License, which permits use, sharing, adaptation, distribution and reproduction in any medium or format, as long as you give appropriate credit to the original author(s) and the source, provide a link to the Creative Commons licence, and indicate if changes were made. The images or other third party material in this article are included in the article's Creative Commons licence, unless indicated otherwise in a credit line to the material. If material is not included in the article's Creative Commons licence and your intended use is not permitted by statutory regulation or exceeds the permitted use, you will need to obtain permission directly from the copyright holder. To view a copy of this licence, visit http://creativecommons.org/licenses/by/4.0/.

\section{References}

Acolas ML, Castelnaud G, Lepage M, Rochard E (2011) Biological cycles and migrations of Acipenser sturio. In: Williot P (ed) Biology and conservation of the European Sturgeon Acipenser sturio L. 1758. Springer, Berlin, pp 147-152. https://doi.org/10.1007/978-3-642-20611-5_10

Bain MB (1997) Atlantic and shortnose sturgeons of the Hudson River: common and divergent life history attributes. Dev Environ Biol Fishes 48(1-4):347-358. https://doi.org/10.1023/A:1007325814 893 
Bain M, Haley N, Peterson D, Waldman JR, Arend K (2000) Harvest and habitats of Atlantic sturgeon Acipenser oxyrinchus Mitchill, 1815 in the Hudson River estuary: Lessons for sturgeon conservation. Boletin-Instituto Espanol De Oceanografia 16 (1/4):43-54. ISSN: 0074-0195

Baldner L (1666) Das Vogel-Fisch-und Thierbuch des Strassburger Fischers Leonhard Baldner aus dem Jahre 1666

Bemis WE, Kynard B (1997) Sturgeon rivers: an introduction to Acipenseriform biogeography and life history. Environ Biol Fishes 48(1-4):167-183. https://doi.org/10.1023/A:1007312524792

Berendsen HJA, Stouthamer E (2000) Late Weichselian and Holocene palaeogeography of the RhineMeuse delta, the Netherlands. Palaeogeogr Palaeoclimatol Palaeoecol 161(3-4):311-335. https:// doi.org/10.1016/S0031-0182(00)00073-0

Billard R, Lecointre G (2000) Biology and conservation of sturgeon and paddlefish. Rev Fish Biol Fisheries 10(4):355-392. https://doi.org/10.1023/A:1012231526151

Birstein VJ, Bemis WE, Waldman JR (1997) The threatened status of acipenseriform species: a summary. In: Birstein VJ, Waldman JR, Bemis WE (eds) Sturgeon biodiversity and conservation. Developments in environmental biology of fishes, vol 17. Springer, Dordrecht, pp 427-435. https:// doi.org/10.1007/0-306-46854-9_33

Blackstone W (1830) Commentaries on the Laws of England in Four Books (1765-69) Vol.1. Collins \& Hannay

Bloesch J, Sieber U (2003) The morphological destruction and subsequent restoration programmes of large rivers in Europe. Large Rivers 14(3-4):363-385. https://doi.org/10.1127/1r/14/2003/363

Böcking W (1988) So fischte man am Niederrhein: die einstigen Fangmethoden von Emmerich bis Neuss; Bilder eines alten Handwerks. Boss-Verlag. ISBN-10: 3922384250

Boddeke R (1971) Vissen \& vissen: ervaringen van een visserijbioloog en sportvisser. Elsevier, Amsterdam

Borcherding J, Heynen M, Jäger-Kleinicke T, Winter HV, Eckmann R (2010) Re-establishment of the North Sea houting in the River Rhine. Fish Manag Ecol 17(3):291-293. https://doi.org/10.1111/j. 1365-2400.2009.00710.x

Brandt JF, Ratzeburg JTC (1833) Medizinische Zoologie oder getreue Darstellung und Beschreibung der Thiere die in die Artzneimittellehre in Betracht kommen is systematischer Folge herausgegeben. Zweiter Band. Hirschwald, Berlin

Brehm AE (1900) Het leven der dieren. Derde deel. Kruipende dieren - Visschen - Insecten - Lagere dieren. (3):243-481. Van Belkum, Zutphen

Brevé NWP, Vis H, Houben B, de Laak G, Breukelaar A, Acolas M, de Bruijn Q, Spierts I (2014) Exploring the possibilities of seaward migrating juvenile European sturgeon Acipenser sturio L., in the Dutch part of the River Rhine. J Coast Conserv 18(2):131-143. https://doi.org/10.1007/s11852-013-0281-0

Brevé NWP, Vis H, Houben B, Breukelaar A, Acolas ML (2019) Outmigration pathways of stocked juvenile European sturgeon (Acipenser sturio L., 1758) in the Lower Rhine River, as revealed by telemetry. J Appl Ichthyol 35(1):61-68. https://doi.org/10.1111/jai.13815

Brevé NWP, Nagelkerke LAJ, Buijse AD, Van Tuijn T, Murk AJ, Winter HV, Lenders HJR (2022) Data underlying the publication: Historical reconstruction of sturgeon (Acipenser spp.) spatiotemporal distribution and causes for their decline in North-Western Europe. https://doi.org/10.17026/dans-xns-5c7c

Bürger F (1926) Die Fischereiverhältnisse im Rhein im Bereich der preußischen Rheinprovinz. Z Fisch 24:217-398

Chassaing O, Desse-Berset N, Hänni C, Hughes S, Berrebi P (2016) Phylogeography of the European sturgeon (Acipenser sturio): a critically endangered species. Mol Phylogenet Evol 94(Pt A):346357. https://doi.org/10.1016/j.ympev.2015.09.020

Council of Europe (2018) Pan-European Action Plan for Sturgeons. T-PVS/Inf(2018)6. Convention on the Conservation of European Wildlife and Natural Habitats. Standing Committee 38th meeting, 27-30 November 2018, Strasbourg

De Groot SJ (2002) A review of the past and present status of anadromous fish species in the Netherlands: is restocking the Rhine feasible? Hydrobiologia 478(1):205-218. https://doi.org/10.1007/ 978-94-017-1335-1_11

De Jong DJ, Parel P, Verdonk J, Den Breejen P, Van der Esch J (1988) Hardinxveld en de riviervisserij. Historische Vereniging Hardinxveld-Giessendam p 405

Deelder CL, Huussen AH Jr (1973) Opmerkingen betreffende de kuilvisserij op de voormalige Zuiderzee, voornamelijk in de zestiende eeuw. Holland 5(5):221-242

Demoll R, Maier HN (1940) Handbuch der Binnenfischerei Mitteleuropas, vol III. B. Schweizerbart'sche Verlagsbuchhandlung, Stuttgart, p 336

Engelhard GH (2008) One hundred and twenty years of change in fishing power of English North Sea trawlers. Adv Fisher Sci 50:1-25 
Ennema JHP (1946) Kampen De aloude Hanzestad. Heemschutserie 47, Allert de Lange pp 121. https:// www.lastdodo.com/en/items/6662495-kampen

Fortibuoni T, Libralato S, Arneri E, Giovanardi O, Solidoro C, Raicevich S (2017) Fish and fishery historical data since the 19th century in the Adriatic Sea. Mediterr Sci Data 4(1):1-13. https://doi.org/10. 1038/sdata.2017.104

Gessner J, Arndt GM, Tiedemann R, Bartel R, Kirschbaum F (2006) Remediation measures for the Baltic sturgeon: status review and perspectives. J Appl Ichthyol 22:23-31. https://doi.org/10.1111/j.14390426.2007.00925.x

Gessner J, Fredrich F, Arndt GM, Von Nordheim H (2010) Conserving and reintroducing the Atlantic sturgeon in North and Baltic Sea tributaries. Natur Landschaft (Stuttgart) 85(12):514-519. https://doi.org/ 10.17433/12.2010.50153053.514-519

Gessner J, Spratte S, Kirschbaum F (2011) Historic Overview on the Status of the European Sturgeon (Acipenser sturio) and Its Fishery in the North Sea and Its Tributaries with a Focus on German Waters. In: Williot P, Rochard E, Desse-Berset N, Kirschbaum F, Gessner J (eds) Biology and conservation of the European Sturgeon Acipenser sturio L. 1758. Springer, Berlin

Gesner J, Williot, P., Rochard, E., Freyhof, J. \& Kottelat, M. (2010) Acipenser sturio. The IUCN Red List of Threatened Species 2010: e.T230A13040963. https://doi.org/10.2305/IUCN.UK.2010-1.RLTS.T230A 13040963.en

Haidvogl G, Lajus D, Pont D, Schmid M, Jungwirth M, Lajus J (2014) Typology of historical sources and the reconstruction of long-term historical changes of riverine fish: a case study of the Austrian Danube and northern Russian rivers. Ecol Freshw Fish 23(4):498-515. https://doi.org/10.1111/eff.12103

Hartmann GL (1827) Helvetische Ichthyologie: oder ausführliche Naturgeschichte der in der Schweiz sich vorfindenden Fische. Orell Füssli und Co, Zürich

Hoek PPC (1894) Mededeelingen over visscherij; maandblad in overleg met het College voor de Zeevisscherijen, vol 1. De Boer, Helder p 188

Hoek PPC (1900) Mededeelingen over visscherij; maandblad in overleg met het College voor de Zeevisscherijen, vol 7. De Boer, Helder p 205

Hoek PPC (1910) De achteruitgang der steurvisscherij onzer benedenrivieren. Mededeelingen over Visscherij maandblad met gebruikmaking van officieele bescheiden, vol 17:103-124. De Boer, Helder

Hoffman R (1996) Economic development and aquatic ecosystems in Medieval Europe. Am Hist Rev 101(3):631-669. https://doi.org/10.1086/ahr/101.3.631

Holčík J (1989) The Freshwater Fishes of Europe: General Introduction to Fishes. 464 p. Acipenseriformes. Aula-Verlag, Balogh Scientific Books ISBN 10: 3891044313

Holčík J, Kinzelbach R, Sokolov L, Vasil'ev V (1989) Acipenser sturio Linnaeus, 1758. Freshwater Fishes Europe 1(pt 2):367-394

Huijbregt PJ (1984) De Zalmzegenvisserij in de Lek bij Ammersloot. Holland, Regionaal-historisch tijdschrift 16(3-4):200-206

Hundt M, Scharbert A, Weibel U, Kuhn G, Metzner K, Jatteau P, Pies A, Schulz R, Gergs R (2015) Chapter VII: First evidence of natural reproduction of the Allis shad Alosa alosa (L. 1758) in River Rhine following reintroduction measures. Aquaculture, conservation and restoration of anadromous fish populations of River Rhine with particular regard to the re-introduction of the Allis shad Alosa alosa 87 (2):37. https://doi.org/10.1111/jfb.12721

ICPR (2018) International Commission for Protection of the Rhine, Bericht Nr. 247. „Masterplan Wanderfische Rhein 2018" -eine Aktualisierung des Masterplans 2009 https://www.iksr.org/fileadmin/user_ upload/DKDM/Dokumente/Fachberichte/DE/rp_De_0247.pdf. Accessed 12 November 2021

IUCN/SSC (2013) Guidelines for Reintroductions and Other Conservation Translocations. Version 1.0. edn. Gland, Switzerland: IUCN Species Survival Commission https://portals.iucn.org/library/efiles/docum ents/2013-009.pdf Accessed 9 July 2021

Jego S, Gazeau C, Jatteau P, Elie P, Rochard E (2002) Les frayères potentielles de l'esturgeon européen Acipenser sturio 1. 1758 dans le bassin Garonne-Dordogne. Méthodes d'investigation, état actuel et perspectives. Bull Franç de la Pêche et de la Pisciculture 365-366:487-505. https://doi.org/10.1051/ kmae:2002047

Kinzelbach R (1987) Das ehemalige Vorkommen des Störs, Acipenser sturio (Linnaeus, 1758), im Einzugsgebiet des Rheins (Chondrostei: Acipenseridae). Z Angewandte Zool 74(2):167-200

Kinzelbach R (1997) The sturgeon (Acipenser sturio L. 1758) in Europe. Z Ökol Natursch 6:129-135

Kolman R, Kapusta A, Duda A, Szczepkowski M, Wiszniewski G, Sakowicz S (2011) Recovery of Baltic sturgeon Acipenser oxyrinchus Mitchill in Poland: sturgeon restocking programme gives positive results. EUROFISH Magazine 5:47-48 
Lassalle G, Crouzet P, Gessner J, Rochard E (2010) Global warming impacts and conservation responses for the critically endangered European Atlantic sturgeon. Biol Cons 143(11):2441-2452. https://doi.org/ 10.1016/j.biocon.2010.06.008

Lenders HJR (2017) Fish and fisheries in the Lower Rhine 1550-1950: a historical-ecological perspective. J Environ Manage 202:403-411. https://doi.org/10.1016/j.jenvman.2016.09.011

Lenders HJR, Chamuleau TPM, Hendriks AJ, Lauwerier RCGM, Leuven RSEW, Verberk WCEP (2016) Historical rise of waterpower initiated the collapse of salmon stocks. Sci Rep 6(1):1-9. https://doi.org/ 10.1038/srep29269

Leuthner F (1877). Die mittelrheinische Fischfauna mit besonderer Berücksichtigung des Rheins bei Basel: nebst einer mit kurzen Diagnosen versehenen systematischen Übersicht zur Bestimmung der rheinischen Fische. Basel; Geneva; Lyon: H. Georg 59 p.

List of Libraries Damaged During World War II. (2021, 31 juli). In Wikipedia. https://en.wikipedia.org/ wiki/List_of_libraries_damaged_during_World_War_II. Accessed 18 November 2021

Martens PJM (1992) De zalmvissers van de Biesbosch: een onderzoek naar de visserij op het Bergse Veld, 1421-1869. Dissertation, Katholieke Universiteit Brabant Tilburg

Mohr E (1952) Der Stör. Die neue Brehm-Bücherei, Heft 84, Akademische Verlagsgesellschaft Geest and Portig K.-G., Leipzig, 66 p. ISBN: 978-3-89432-564-0

Nemitz A (2010) Perspektiven für eine Wiederansiedlung des Europäischen Störs (Acipenser sturio L., 1758) im Einzugsgebiet des Rheins. Unveröffentlichte Studie des Rheinischen Fischereiverbands

OSPAR Commission (2021) BDC2020/European or Common sturgeon. 2020 Status Assessment European Sturgeon. https:/oap.ospar.org/en/ospar-assessments/committee-assessments/biodiversitycommittee/status-assesments/european-or-common-sturgeon/ Accessed 9 July 2021

Paaver T (1999) Historic and recent records of native and exotic sturgeon species in Estonia. J Appl Ichthyol 15(4-5):129-132. https://doi.org/10.1111/j.1439-0426.1999.tb00221.x

Puijenbroek PJTM, Buijse AD, Kraak MHS, Verdonschot PFM (2019) Species and river specific effects of river fragmentation on European anadromous fish species. River Res Appl 35(1):68-77. https:// doi.org/10.1002/rra.3386

Quantz H (1903) Störfischerei und Störzucht im Gebiet der deutschen Norseeküste [Sturgeon fishery and sturgeon reproduction in the area of the German North sea coast]. Mitt Des Deutsch Seefisch-Ver 19(6):176-204

Redeke HC (1915) Mededeelingen over Visscherij maandblad met gebruikmaking van officieele bescheiden uitgegeven door Dr. H. C. Redeke, vol 22. De Boer, Helder. p 702

Reekers FJMA (1916) Verslag van de Staatscommissie voor het Zalmvraagstuk / Deel I. Algemeene Landsdrukkerij, 's-Gravenhage. pp 91

Rochard E, Castelnaud G, Lepage M (1990) Sturgeons (Pisces: Acipenseridae); threats and prospects. J Fish Biol 37:123-132. https://doi.org/10.1111/j.1095-8649.1990.tb05028.x

Sahrhage D, Lundbeck J (2012) A history of fishing. Springer Science \& Business Media, Berlin

Spratte S (2014) Störe in Schleswig-HolsteinVergangenheit - Gegenwart - Zukunft. Landesamt für Landwirtschaft, Umwelt und ländliche Räume des Landes Schleswig-Holstein (LLUR), Flintbek. ISBN: 978-3-937937-74-8

Staas S (2017) Evaluation of potential reproductive habitats of European sturgeon in the Lower Rhine River in Germany. LimnoPlan, pp 53

Steenhuis M (2015) The Deltaworks: heritage and new space for a changing world. Water \& heritage. Material, conceptual and spiritual connections. Sidestone Press, Leiden, pp 331-350

Sulak KJ, Parauka F, Slack WT, Ruth RT, Randall MT, Luke K, Mettee MF, Price ME (2016) Status of scientific knowledge, recovery progress, and future research directions for the gulf sturgeon, Acipenser oxyrinchus desotoi vladykov, 1955. J Appl Ichthyol 32:87-161. https://doi.org/10.1111/jai. 13245

Thieren E, Ervynck A, Brinkhuizen D, Locker A, Van Neer W (2016) The Holocene occurrence of Acipenser spp. in the southern North Sea: the archaeological record. J Fish Biol 89(4):1958-1973. https://doi.org/10.1111/jfb.13094

Thieren E, Van Neer W (2016) Scutes for sturgeon size reconstruction: traditional and geometric morphometric techniques applied to Acipenser sturio and A. oxyrinchus. Archaeofauna. https://doi.org/ 10.15366/archaeofauna2016.25

Thieren E, Wouters W, Van Neer W (2015) Guide for the identification of archaeological sea sturgeon (Acipenser sturio and A. oxyrinchus) remains. Cybium 39(3):175-192. https://doi.org/10.26028/ cybium/2015-393-002

Uehlinger UF, Wantzen KM, Leuven RS, Arndt H (2009) The Rhine river basin. First publ. in: Rivers of Europe I Klement Tockner u.a. - London: Acad. Pr., 2009, pp. 199-245 - ISBN 978-0-12-369449-2 
Van der Hoeven H, Van Albada J (1996) Lost memory: libraries and archives destroyed in the twentieth century. UNESCO, Paris, p 70

Van Emmerik WAM (2004) Kennisdocument Atlantische steur Acipenser sturio (Linnaeus, 1758). Kennisdocument 02. OVB / Sportvisserij Nederland, Bilthoven

Van Erp M, De Does J, Depuydt K, Lenders R, van Goethem T (2018) Slicing and dicing a newspaper corpus for historical ecology research. In: Faron Zucker C, Ghidini C, Napoli A, Toussaint Y (eds) Knowledge engineering and knowledge management. EKAW (2018) Lecture notes in computer science, vol 11313. Springer Nature Switzerland, Basel, pp 470-484. https://doi.org/10.1007/978-3030-03667-6_30

Van Neer W, Thieren E, Brinkhuizen D (2012) Identification of a 19th century sturgeon from North-East Friesland. In: Raemaekers DCM et al (eds) A Bouquet of archaeozoological studies: essays in honour of Wietske Prummel, vol 21. Barkhuis, Haren

Van Zanden JL (2013) Prices and wages and the cost of living in the western part of the Netherlands, 1450-1800. Visited online at the International Institute of Social History, http://iisg.nl/hpw/brenv.php, Amsterdam. Accessed 12 November 2021

Verhey C (1900) Het voorkomen van de Steur (Acipenser sturio L.) in de Nieuwe Merwede tussen 1900 en 1931. De Levende Natuur 52(8):152-159

Villamayor-Tomas S, Fleischman FD, Ibarra IP, Thiel A, Van Laerhoven F (2014) From Sandoz to Salmon: conceptualizing resource and institutional dynamics in the Rhine watershed through the SES framework. Int J Commons 8(2):361-395. https://doi.org/10.18352/ijc.411

Von Boetticher W (1886) Lachsvertrag NL-DE. No18: 191-202 Reichs Gesetzblatt. Berlin.

Williot P, Arlati G, Chebanov M, Gulyas T, Kasimov R, Kirschbaum F, Patriche N, Pavlovskaya LP, Poliakova L, Pourkazemi M (2002) Status and management of Eurasian sturgeon: an overview. Int Rev Hydrobiol 87(5-6):483-506. https://doi.org/10.1002/1522-2632(200211)87:5/6\%3c483::AID-IROH4 $83 \% 3 \mathrm{e} 3.0 . \mathrm{CO} ; 2-\mathrm{K}$

Williot P, Castelnaud G (2011) Historic overview of the European sturgeon Acipenser sturio in France: surveys, regulations, reasons for the decline, conservation, and analysis. In: Williot P (ed) Biology and conservation of the European Sturgeon Acipenser sturio L 1758. Springer, Berlin, pp 285-307. https:// doi.org/10.1007/978-3-642-20611-5_20

Williot P, Kirschbaum F (2011) The French-German cooperation: the key issue for the success of the preservation and restoration of the European sturgeon, Acipenser sturio, and its significance for other sturgeon issues. In: Williot P (ed) Biology and conservation of the European Sturgeon Acipenser sturio L. 1758. Springer, Berlin, pp 499-513. https://doi.org/10.1007/978-3-642-20611-5_38

Williot P, Rouault T, Brun R, Gessner J (2011) Characteristics of the reproductive cycle of wild acipenser sturio. In: Williot P, Rochard E, Desse-Berset N, Kirschbaum F, Gessner J (eds) Biology and conservation of the European Sturgeon Acipenser sturio L. 1758. Springer, Berlin, pp 165-175. https://doi.org/ 10.1007/978-3-642-20611-5_12

Wolff W, Dankers N, Dijkema K, Reijnders P, Smit C (1994) Biodiversity of the Wadden Sea (Denmark, Germany, The Netherlands): recent changes and future projections. In: Boyle TB (ed) Biodiversity, temperate ecosystems, and global change. Springer, Brlin, pp 337-355. https://doi.org/10.1007/978-3642-78972-4_18

Zeevisscherij J (1912) Eerste jaarverslag der Commissie van Zeevisscherij. Brugge, Verbeke-Loys \& Cie, p 145

Zeevisscherij J (1925) Negende jaarverslag der Commissie van Zeevisscherij. Brugge, Verbeke-Loys \& Cie, p 102

Zeevisscherij J (1936) Bestuurlijk Jaarverslag over de Zeevisscherij 1936. Brugge, Verbeke-Loys \& Cie, p 57

Publisher's Note Springer Nature remains neutral with regard to jurisdictional claims in published maps and institutional affiliations. 


\section{Authors and Affiliations}

Niels W. P. Brevé ${ }^{1,2,3}$ (D) . Leopold A. J. Nagelkerke ${ }^{1}$ (D) . Anthonie D. Buijse ${ }^{1,4}$ (D) Theodorus J. van Tuijn ${ }^{5}$ (D) AlberTinka J. Murk ${ }^{2}$ (D) Hendrik V. Winter ${ }^{1,6}$ (D) H. J. Rob Lenders ${ }^{5}$ (D)

1 Aquaculture \& Fisheries Group, Wageningen University, De Elst 1, 6708 WD Wageningen, The Netherlands

2 Marine Animal Ecology Group, Wageningen University, Droevendaalsesteeg 1, 6708 PB Wageningen, The Netherlands

3 The Royal Dutch Angling Alliance, Sportvisserij Nederland, Leijenseweg 115, 3721 BC Bilthoven, The Netherlands

4 Department of Freshwater Ecology \& Water Quality, Deltares, Boussinesqweg 1, 2629 HV Delft, The Netherlands

5 Department of Environmental Science, Faculty of Science, Radboud University Nijmegen, Heyendaalseweg 135, 6525 AJ Nijmegen, The Netherlands

6 Wageningen Marine Research, Wageningen University \& Research, Haringkade 1, 1976 CP IJmuiden, The Netherlands 